\title{
The Effects of Foot Touch Therapy on Blood Pressure in Hypertension Patients in The Puskesmas Of Dlanggu Mojokerto
}

\author{
Indra Yulianti*, Rina Mardiyana \\ STiKes Bina Sehat PPNI Mojokerto, Indonesia \\ *indray85@gmail.com
}

\begin{abstract}
Hypertension is a disease of the cardiovascular system which is one of the causes of high mortality and morbidity. The anti-hypertensive drugs taken contain chemicals with various side effects and are used for life. One of the treatments for non-pharmacological hypertension is touch therapy. This study aims to determine the effects of foot touch therapy to reduce blood pressure of hypertensive sufferers.

This research employed a Quasi Experiment design with a Non-Equivalent Control Group design. The population ofthe treatment group and control group were patients with grade 1 hypertension consisting of 30 treatment groups and 30 control groups. The treatment group receivedfoot touch therapy for 5 consecutive days for 15-20 minutes. Meanwhile, the measurement of blood pressure employeda digital blood meter. The data processing and data analysis employedpaired t test, and the effectiveness test employed ancova test.

The results of the studyreveals that the systolic blood pressure increases by $13.6 \mathrm{mmHg}$ and the diastolic decreases in diastolic blood pressure by $8.5 \mathrm{mmHg}$. The result showsp value $0.000<\alpha$, and it is concluded that $\mathrm{H} 0$ is rejected and means that Foot Touch Therapy against blood pressure for patients with hypertension effectively reduces systolic blood pressure. The therapy model is considered good by $72.8 \%$. The results of the analysis of the equivalence test in the diastolic variable group using the Levene's test obtained $p$ value $>\alpha$.It can be concluded that the data is homogeneous. The Ancova analysis results obtain F count 82.53 and p-value $0.000<\alpha$, it can be concluded that $\mathrm{H} 0$ is rejected. It means that foottouch therapy against blood pressure in patients with hypertension effectively reduces diastolic blood pressure. The model of therapy is quite good by $62 \%$.

Foot touch therapy technique done with 15-20 minute- massage is proven to effectively reduce systolic and diastolic blood pressure in people with hypertension. Based on the results of the study, it is recommended to conduct further research by applying touch therapy to patients with severe hypertension.
\end{abstract}

Keywords: Touch Therapy, Blood Pressure, Hypertension 


\section{STRADA Jurnal Ilmiah Kesehatan}

DOI: $10.30994 /$ sjik.v9i2.464

ISSN: 2252-3847 (print); 2614-350X (online)

Vol.9 No.2 November 2020 Page.1268-1273

\section{BACKGROUND}

Hypertension is one of the leading causes of death worldwide, but it can be prevented by pharmacological and non-pharmacological treatments. Hypertension is a major risk factor for mortality and isthe third leading risk factor for disease burden that affects approximately one billion people worldwide in both developed and developing countries (1). Hypertension is a health problem that can attackanyone regardless of gender, age, and posture. Previously, hypertension only attacks the elderly, but because of an unhealthy lifestyle such as smoking, lack of exercise, eating less nutritious food, and stress, hypertension can attack young adults of 21-40 years old (2). Hypertension can be controlled with pharmacological therapy and non-pharmacological therapy. Dissatisfaction with conventional medical practice, dissatisfaction with the level of success in medical services and to reduce side effects of conventional therapy used (3). Hypertension sufferers need a non-pharmacological method in the form of an innovative foot touch therapy to reduce blood pressure in hypertensive patients.

Non-pharmacological methods, such as massage may effectively balance blood pressure and solve sleep problems. Six sessions of foot massage and back massage are detected to successfully decrease values of systolic blood pressure (SBP) and diastolic blood pressure (DBP), and the differences are statistically significant ( $\mathrm{p}<0.001)$. Foot and back massage can effectively reduce blood pressure and improve sleep quality (4). Hypertension sufferers in the world continue to increase significantly and have reached almost one third of the population. Although in general it can be treated on an outpatient basis, most of them are hospitalized if they leave unchecked.High blood pressure will cause organ damage although sometimes patients are asymptomatic (5). The 2018 Riskesdas reports that hypertension occurs in the age group 31-44 years (31.6\%), 45-54 years old (45.3\%), and 55-64 years old (55.2\%). The prevalence of 34.1\% of hypertension showsthat $8.8 \%$ of people are diagnosed with hypertension, $13.3 \%$ of people are diagnosed with hypertension without taking medication, and $32.3 \%$ of people are diagnosed with hypertension with regular medication (6). The results of the Clinical Trial conducted in Ngembeh Village/Dlanggu-Mojokerto District on July 24, 2019 show that the measurement of blood pressure in 5 patients with mild to moderate hypertension revealsthat 4 out of 5 hypertension sufferers never receive Touch Therapy to lower blood pressure. Patients who have undergone a three-day touch therapy say that they feel less headache and experience a decrease in an average of $10 \mathrm{mmHg}$ systole and $5 \mathrm{mmHg}$ diastole.

Non-pharmacological effort to lower blood pressure are employing the Touch Therapy Technique by touching and pressing the leg to influence the muscle nerves to relax. Therefore, it can work to affect the vasodilation of peripheral vessels, and the effect is to facilitate the flow of blood back from the lower limb to the heart. Foot consists of many nerves connected to all organs both outside and inside the human body, one of which helps reduce blood pressure in people with hypertension (7).

\section{METHOD}

The research employed a quasi-experiment design with a non-equivalent control group design (8). The population of this study were hypertension patients who met the research criteria, such asmild to moderate hypertension sufferers, patients without taking hypertension medication during the study, and patients without other accompanying complications. The independent variable of this study was blood pressure and the dependent variable was touch therapy. Blood pressure patients with screened hypertension 


\section{STRADA Jurnal Ilmiah Kesehatan}

DOI: $10.30994 /$ sjik.v9i2.464

ISSN: 2252-3847 (print); 2614-350X (online)

Vol.9 No.2 November 2020 Page.1268-1273

measured their blood pressure before the intervention. Then, the samples of this study were mild to moderate hypertension patients divided into 2 groups, namely the treatment group (with intervention) and the control group (without intervention). On day 1 to day 5 the treatment group received the touch therapy for 15-20 minutes while in the control group received without treatment. The blood pressure of two groups was measured again on day 5. The blood pressure was measured by usinga digital blood meter. The data processing and data analysis employed paired $t$ test, and the effectiveness test employed ancova test.

\section{RESULTS}

Table 1. The results of the systolic and diastolic normality test in the treatment group of hypertension sufferers

\section{One-Sample Kolmogorov-Smirnov Test}

\begin{tabular}{|c|c|c|c|c|c|c|}
\hline \multirow{2}{*}{ Variabel } & \multicolumn{2}{|l|}{ Mean } & \multicolumn{2}{|c|}{ Std. Deviation } & \multicolumn{2}{|l|}{$p$ value } \\
\hline & Before & After & Before & After & Before & After \\
\hline Systolic & $\begin{array}{l}151.3 \\
\mathrm{mmHg}\end{array}$ & $\begin{array}{l}137.7 \\
\mathrm{mmHg}\end{array}$ & 5.7 & 6.5 & 0.745 & 0.836 \\
\hline Diastolic & $\begin{array}{l}90.5 \\
\mathrm{mmHg}\end{array}$ & $\begin{array}{l}81 \\
\mathrm{mmHg}\end{array}$ & 6.3 & 7.8 & 0.077 & 0.290 \\
\hline
\end{tabular}

The results of the analysis of the pre- and post-systolic variable data of normality test in the treatment group using the Kolmogorov-Smirnov test shows $\mathrm{p}$ value> 0.05.It can be concluded that the above data is normally distributed. The results of the data normality test analysis of the pre and post diastolic variables in the treatment group using the Kolmogorov-Smirnov test show $\mathrm{p}$ value> 0.05.It can be concluded that the above data is normally distributed.

Table 2 The results of testing the effectiveness of Touch Therapy on the Feet against Blood Pressure of Hypertension Patients

\begin{tabular}{|c|c|c|c|c|c|c|c|}
\hline \multirow[b]{2}{*}{ Variabel } & & \multirow[b]{2}{*}{ Mean } & \multicolumn{2}{|c|}{ Levene's test } & \multirow[b]{2}{*}{$\mathrm{F}$} & \multirow[b]{2}{*}{ p-value } & \multirow[b]{2}{*}{$R$ Square } \\
\hline & & & $\mathrm{F}$ & $\begin{array}{l}p- \\
\text { value }\end{array}$ & & & \\
\hline \multirow{2}{*}{ Systolic } & Treatment & $\begin{array}{l}137.7 \\
\mathrm{mmHg}\end{array}$ & \multirow{2}{*}{3.25} & \multirow{2}{*}{0.077} & \multirow{2}{*}{140.351} & \multirow{2}{*}{0.000} & \multirow{2}{*}{0.728} \\
\hline & Control & $\begin{array}{l}159.3 \\
\mathrm{mmHg}\end{array}$ & & & & & \\
\hline \multirow[b]{2}{*}{ Diastolic } & Treatment & $\begin{array}{l}81.06 \\
\mathrm{mmHg}\end{array}$ & \multirow[b]{2}{*}{1.136} & \multirow[b]{2}{*}{0.291} & \multirow[b]{2}{*}{82.53} & \multirow[b]{2}{*}{0.000} & \multirow[b]{2}{*}{0.620} \\
\hline & Control & $\begin{array}{l}99.8 \\
\mathrm{mmHg}\end{array}$ & & & & & \\
\hline
\end{tabular}

The results of the analysis of the equivalence test in the systolic variable group using the Levene's test obtain $p$ value $>\alpha$.It can be concluded that the data is homogeneous. The Ancova analysis results obtain $F$ count 140.351 and $p$ value $0.000<\alpha$. It can be concluded that $\mathrm{HO}$ is rejected, and itindicatesthat the foot touch therapy against blood pressure for patients with hypertension is effectively reduce the systolic blood pressure. Good therapy model is $72.8 \%$. The results of the analysis of the equivalence test in the diastolic variable 


\section{STRADA Jurnal Ilmiah Kesehatan}

DOI: $10.30994 /$ sjik.v9i2.464

ISSN: 2252-3847 (print); 2614-350X (online)

Vol.9 No.2 November 2020 Page.1268-1273

group using the Levene's test obtain $\mathrm{p}$ value $>\alpha$. It can be concluded that the data is homogeneous. Ancova analysis results obtain F count 82.53 and p-value $0.000<\alpha$. It can be concluded that $\mathrm{H} 0$ is rejected, and it indicates that foot touch therapy blood pressure in patients with hypertension is effectively reduce diastolic blood pressure. The model of therapy is quite good, namely $62 \%$. Therefore, the results of the analysis prove that touch therapy on the feet can reduce the blood pressure of hypertension patients.

\section{DISCUSSION}

The results of paired t-test analysis on the systolic variable revealthat the systolic blood pressure decreaseby $13.6 \mathrm{mmHg}$ after the patients with hypertension receive foot touch therapy against blood pressure. The value of confidence interval shows $>1$ and the pvalue $0.000<\alpha$. It is concluded that $\mathrm{H}_{0}$ isrejected, and it indicates that there isan effect of touch therapy on the feet against blood pressure in hypertensive patients. The results of paired t-test analysis on diastolic variables findthat diastolic blood pressure decreases by $8.5 \mathrm{mmHg}$ after the patients with hypertension receivefoot touch therapy against blood pressure of patients with hypertension. The value of confidence interval shows $>1$ and pvalue of $0.000<\alpha$.It can be concluded that $\mathrm{H} 0$ is rejected, and it indicatesthat there is an effect of foot touch therapy on blood pressure of hypertension patients.

Hypertension often causes no symptoms, while blood pressure that is persistently high for a long time can cause complications $(9)(9,10)$. A study by (11)Widyastuti $(2014)$ posits that people with hypertension can be treated in a non-pharmacological way by massage/touch therapy in whichthe massage is done by touching and pressing parts of the body to influence the muscle nerves to relax. As the result, they can work optimally according to their function. This massage causes vasodilation of the peripheral vessels, and the effect is to facilitate the return of blood flow from the lower extremity to the heart in which the feet have many nerves that are connected to all organs both outside and inside the human body to lower blood pressure. One of the movements in massage, namely effleurage done on flat feet, causes vasodilation of peripheral blood vessels and can accelerate the return of blood flow from the lower limb to the heart (12). Massage can reduce systolic and diastolic pressure if it is done for 20-30 minutes every day, and it is very useful for maintaining the heart and blood circulation.

The results of paired t-test analysis on the systolic variable findthat the systolic blood pressure increases by $8 \mathrm{mmHg}$ after the hypertension patients receive foot touch therapy against blood pressure, and the value of confidence interval is $>1$ and p-value of 0.000 $<\alpha$.It is concluded that $\mathrm{H}_{0}$ is rejected, and it indicates that there isan effect of foot touch therapy against blood pressure. The results of paired t-test analysis on diastolic variables revealthat diastolic blood pressure increases by $7.5 \mathrm{mmHg}$ after the patients with hypertension receive foot touch therapy against blood pressure. The value of confidence interval is $>1$ and p-value of $0.000<\alpha$. It can be concluded that $\mathrm{H}_{0}$ is rejected, and it means that there is an effect of foot touch therapy against blood pressure of hypertension patients.

Massage is an action that provides relaxation because the sympathetic nervous system has decreased activity result in a decrease in blood pressure, and a massage is a passive form that can increase blood circulation in the body (13). The stimulation caused to the nerve receptors also causes the blood vessels to expand spontaneously, thereby increasing blood flow. The stimulation given can increase the flow of blood and body fluids. The result is that the circulation of nutrients and oxygen to the body's cells becomes 


\section{STRADA Jurnal Ilmiah Kesehatan}

DOI: $10.30994 /$ sjik.v9i2.464

ISSN: 2252-3847 (print); 2614-350X (online)

Vol.9 No.2 November 2020 Page.1268-1273

smooth without any obstacles. Smooth blood circulation provides a relaxing and refreshing effect on all members of the body so that the body experiences a balanced condition (14).

The increase in blood pressure that occur in the control group both in systole and diastole iscaused by many factors including uncontrolled eating patterns and irregular exercises. Several factors that can affect changes in systolic blood pressure are the return of blood through the veins or the amount of blood returning to the heart through the veins (15). If blood returns to decrease, the heart muscle will not be distended, and the ventricular strength in the systolic phase will decrease and blood pressure will decrease (16). Furthermore, blood viscosity can also affect systolic blood pressure. Normal blood viscosity depends on the presence of red blood cells and plasma proteins, especially albumin. A person's red blood cell levels are too high, and it causes an increase in blood viscosity and blood pressure. When doing massage on the leg muscles, increase them gradually to relax the tension so that it can help increase blood flow to the heart and blood pressure will drop (17).

\section{CONCLUSION}

Foot touch therapy technique is done with a 20 to 30 minute-massage is proven to effectively reduce systolic and diastolic blood pressure ofpeople with hypertension. The results of the study recommend other scholars to conduct further research by applying touch therapy to patients with severe hypertension. Further research cancontinue to compare the effectiveness of foot touch therapy by combining with hypertension drugs in patients with chronic and severe hypertension to a decrease in systolic and diastolic blood pressure.

\section{REFERENCES}

1. Xiong XJ, Li SJ, Zhang YQ. Massage therapy for essential hypertension: a systematic review. J Hum Hypertens. 2015;29(3):143-51.

2. Hayes P, Casey M, Glynn LG, Molloy GJ, Durand H, O’Brien E, et al. Measuring adherence to therapy in apparent treatment-resistant hypertension: a feasibility study in Irish primary care. Br J Gen Pract. 2019;

3. Pratiwi. Ika. Analisis Faktor-Faktor Yang Mempengaruhi Kepatuhan Pasien Hipertensi Dalam Penggunaan Obat Di RSUD Kardinah. J Politek Harapan Bersama Tegal. 2017;2(1).

4. Arslan, G., Ceyhan, Ö., \& Mollaoğlu M. The influence of foot and back massage on blood pressure and sleep quality in females with essential hypertension: a randomized controlled study. J Hum Hypertens. 2020;1(11).

5. Axon, R. N., Turner, M., \& Buckley R. An Update on Inpatient Hypertension Management. Curr Cardiol Rep. 2015;10(7):doi.org/10.1007/s11886-015-0648-y.

6. Riskesdas. Badan Penelitian dan Pengembangan Kesehatan Kementrian RI. 2018.

7. T.A M. Pengaruh massase (pijat) pada kaki dengan menggunakan minyak essensial zaitun terhadap penurunan tekanan darah pada pasien hipertensi. S1 Keperawatan : Stikes Medistra Lubuk Pakam. Stikes Medistra Lubuk Pakam. 2012; vol 1.

8. Nursalam. Konsep Dan Penerapan Metodologi Penelitian Ilmu Keperawatan. Jakarta: Salemba Medika; 2013.

9. Handoko. Rahasia Pengobatan Neuropati agar tetap sehat \& panjang umur. Jakarta: Gramedia; 2011.

10. Yonata A, Pratama ASP. Hipertensi sebagai faktor pencetus terjadinya stroke. J Major. 2016;5(3):17-21. 


\section{STRADA Jurnal Ilmiah Kesehatan}

DOI: $10.30994 /$ sjik.v9i2.464

ISSN: 2252-3847 (print); 2614-350X (online)

Vol.9 No.2 November 2020 Page.1268-1273

11. Widyastuti Y. Terapi Komplementer dalam Keperawatan. J Keperawatan Indones. 2014;12(1).

12. Black, J dan Hawks J. Keperawatan Medikal Bedah: Manajemen Klinis untuk Hasil yang Diharapkan. Dialihbahasakan oleh Nampira R. Jakarta: Salemba Emban Patria; 2014.

13. Putra. Sehat dengan Terapi Refleksi dan Herbal di Rumah Sendiri. Yogyakarta: Citra AjiParama; 2014.

14. Wade.C. Mengatasi Hipertensi. Bandung : Nuansa Cendekia; 2016.

15. Hartanti, R. D., Wardana, D. P., \& Fajar RA. Terapi relaksasi napas dalam menurunkan tekanan darah pasien hipertensi. J Ilm Kesehat. 2016;9(1).

16. Astuti D. Pengaruh Terapi Healing Touch Terhadap Perubahan Tekanan Darah Pasien Hipertensi Di Desa Tulakan Donorojo Jepara. J Ilmu Keperawatan dan Kebidanan. 2016;7(2).

17. Paramita. Penggunaan Obat Bahan Alami Sebagai Terapi Komplementer Pada Pasien Hipertensi Di Puskesmas. J Sains Dan Kesehat. 2017;1(7). 